\title{
Leukemia relapse following unmanipulated haploidentical transplantation: a risk factor analysis on behalf of the ALWP of the EBMT
}

Simona Piemontese ${ }^{1 *}$, Ariane Boumendil2 ${ }^{2}$, Myriam Labopin ${ }^{2,3,18}$, Christoph Schmid ${ }^{4}$, Fabio Ciceri ${ }^{1,19}$, William Arcese ${ }^{5}$, Yener Koc ${ }^{6}$, Zafar Gulbas ${ }^{7}$, Johanna Tischer ${ }^{8}$, Benedetto Bruno ${ }^{9}$, Depei Wü ${ }^{10}$, Didier Blaise ${ }^{11}$, Dietrich Beelen ${ }^{12}$, Giuseppe Irrera ${ }^{13}$, Annalisa Ruggeri ${ }^{14}$, Mohamed Houhou ${ }^{2,18}$, Mohamad Mohty ${ }^{2,3,15,18}$, Arnon Nagler ${ }^{16,17,18}$ and on behalf of the Acute Leukemia Working Party of the European Society for Blood and Marrow Transplantation (EBMT)

\begin{abstract}
Background: As information on incidence, risk factors, and outcome of acute leukemia (AL) relapse after unmanipulated haploidentical stem cell transplantation (haplo-SCT) is scarce, a retrospective registry study was performed by the Acute Leukemia Working Party of the European Society for Blood and Marrow Transplantation.

Methods: Among 1652 transplants performed for lymphoblastic and myeloid AL between 2007 and 2014, 587 patients (acute lymphoblastic leukemia (ALL) 131, acute myeloid leukemia (AML) 456) with detailed information were analyzed aiming to identify risk factors for post-transplant relapse and for overall survival (OS) after relapse.

Results: The cumulative incidence of relapse at 3 years was 44\% (35-53\%) for ALL and 32\% (27-36\%) for AML ( $p=0.023)$. In ALL, risk factors for relapse were disease status different from the first complete remission (CR1) at haplo-SCT (CR2 vs CR1: HR 2.85, $p=0.011$; advanced vs CR1: HR 14.28, $p<0.0001$ ) and male donor gender (HR 3.64, $p=0.0002$ ), while in AML, risk factors were advanced disease at haplo-SCT (advanced vs CR1: HR 3.95, $p<0.0001$ ) and comorbidities (HCT-Cl) $\geq 3$ (HR 1.75, $p=0.014$ ). Transplants performed in more recent years were associated with lower relapse incidence (RI) in AML, but not in ALL (HR 0.91, $p=0.042$ ). After relapse, median follow-up was 13 months (mos). OS at 1-year post relapse was 18\%. Prognostic factors for superior OS after relapse were remission at time of haplo-SCT (CR vs advanced: HR 0.71, $p=0.028$ ), time from transplant to relapse ( $\geq 5$ mos vs $<5$ mos: HR 0.530, $p<0.0001)$, and bone marrow as a stem cell source (peripheral blood (PB) vs bone marrow (BM): HR 1.473, $p=0.016$ ).

Conclusions: Risk factors for relapse after haploidentical transplantation were disease specific. Longer OS after relapse was achieved in particular by patients both in CR at haplo-SCT and relapsing more than 5 months after transplant (1-year OS 33\%).
\end{abstract}

Keywords: Leukemia relapse, Survival after relapse

\footnotetext{
* Correspondence: piemontese.simona@hsr.it

${ }^{1}$ Hematology and Bone Marrow Transplant Unit, San Raffaele Scientific

Institute, Milan, Italy

Full list of author information is available at the end of the article
}

(c) The Author(s). 2019 Open Access This article is distributed under the terms of the Creative Commons Attribution 4.0 International License (http://creativecommons.org/licenses/by/4.0/), which permits unrestricted use, distribution, and reproduction in any medium, provided you give appropriate credit to the original author(s) and the source, provide a link to the Creative Commons license, and indicate if changes were made. The Creative Commons Public Domain Dedication waiver (http://creativecommons.org/publicdomain/zero/1.0/) applies to the data made available in this article, unless otherwise stated. 


\section{Introduction}

Allogeneic stem cell transplantation (allo-SCT) represents a curative option for intermediate- and high-risk adult acute leukemias (AL). In the absence of a matched donor, haploidentical donors are increasingly used with favorable outcomes [1-5]. Despite substantial improvements in non-relapse mortality (NRM) over the years, relapse of acute leukemia remains the leading cause of failure after allo-SCT. Following haploidentical transplant (haplo-SCT), relapse incidence (RI) ranges from 22 to $30 \%$ [6-9] up to $58 \%$ when reduced intensity conditioning (RIC) regimens are used [10].

In the haplo-SCT setting, major human leukocyte antigen (HLA) mismatches between donor cells and recipient leukemic cells may theoretically serve as potential targets for a strong allogeneic graft vs leukemia (GVL) effect. Nevertheless, recent studies from the Acute Leukemia Working Party (ALWP) of the European Society for Blood and Marrow Transplantation (EBMT) could only show a trend for a lower RI among patients with high-risk acute myeloid leukemia after haplo-SCT in comparison to identical sibling transplants $[11,12]$.

Several single-center-based studies have reported risk factors [13-15] and treatment of leukemia relapse after haplo-SCT [16-19]. Nevertheless, a systematic analysis aiming at identifying risk factors and timing of relapse, and describing possible treatments of leukemia relapse after haplo-SCT is still lacking. For these reasons, we decided to perform a large, registry-based study, using the EBMT-ALWP registry to identify risk factors and assessing outcome of leukemic relapse after haplo-SCT.

\section{Patients and methods}

Inclusion criteria of the study were as follows: age $\geq 18$ years; diagnosis of either acute myeloid (AML) or acute lymphoblasic leukemia (ALL) both de novo and secondary; non-ex vivo $\mathrm{T}$ cell-depleted SCT from a family donor with $\geq 2$ HLA mismatches between donor and recipient; peripheral blood (PB) or bone marrow (BM) as source of SC; first allo-SCT (previous autologous SCT was allowed), regardless of stage at SCT. All patients underwent transplantation between January 2007 and December 2014.

Data for this retrospective multicenter analysis were provided and approved by the ALWP of the EBMT registry. The EBMT is a non-profit, scientific society representing more than 600 transplant centers mainly in Europe. The EBMT promotes all activity aiming to improve stem cell transplantation or cellular therapy, which includes registering all the activity relating to stem cell transplants. Data are entered, managed, and maintained in a central database with internet access; each EBMT center is represented in this database. There are no restrictions on centers for reporting data, except for those required by the law on patient consent, data confidentiality, and accuracy. Quality control measures included several independent systems: confirmation of validity of the entered data by the reporting team, selective comparison of the survey data with minimum essential data A (MED-A) data sets in the EBMT registry database, cross-checking with the National Registries, and regular in-house and external data audits. Since 1990, patients have provided informed consent authorizing the use of their personal information for research purposes.

Definitions and statistical analysis

Primary endpoints were [1] incidence and risk factors of leukemia relapse after transplant and [2] risk factors for overall survival (OS) after relapse. RI after transplant was defined as time from date of transplant to leukemia relapse. NRM was defined as death without evidence of relapse. Death without hematological relapse and relapse were competitive risks for relapse incidence (RI) and NRM, respectively. OS after relapse was defined as time from date of relapse and death from all causes. Acute GVHD was graded according to the modified Seattle Glucksberg criteria [20], and cGVHD according to the revised Seattle criteria [21].

Myeloablative conditioning regimens (MAC) were defined as including total body irradiation (TBI) $>8 \mathrm{~Gy}$, or busulfan $>8 \mathrm{mg} / \mathrm{kg}$, or more than one alkylating agent as per EBMT criteria [22].

The patient's comorbidities were classified using the hematopoietic stem cell transplantation-specific comorbidity index (HCT-CI) according to Sorror et al [23].

The type I error rate was fixed at 0.05 for determination of factors associated with time to event. Multivariate analyses were performed using Cox regression models and stepwise regression procedures. Analyses were performed using the $\mathrm{R}$ statistical software version 3.2.3 (R Development Core Team, Vienna, Austria).

As ALL and AML differ in biology, risk classification, induction treatment, and outcomes including relapse rates [6, 24], and also because of significant differences in patients' characteristics (Table 1), we analyzed these two populations separately.

\section{Results}

Patients' and donors' characteristics and overall outcome

Between January 2007 and December 2014, 1652 adult patients received a Haplo-SCT for acute leukemia. In 587 out of 1652 haplo-SCT (35\%), detailed information on the characteristics of disease and management of relapse was provided by the respective transplant centers, allowing for the analysis of incidence and risk factors of leukemia relapse after transplant (RI) and overall survival (OS) after relapse. This group was well matched to the entire cohort of 1652 patients with respect to sex of 
Table 1. Patients', donors', and disease characteristics

\begin{tabular}{|c|c|c|c|c|}
\hline & $\mathrm{n}^{\circ}$ & $\begin{array}{l}\text { ALL } \\
131\end{array}$ & $\begin{array}{l}\text { AML } \\
456\end{array}$ & p-value \\
\hline Year of transplant & & $2012(2007-2014)$ & 2012 (2007-2014) & 0.2098 \\
\hline Age at SCT & mean (range) & $36.76(18.05-76.08)$ & $48.26(18.01-77.81)$ & $<0.0001$ \\
\hline Donor age & mean (range) & $40.81(15.21-74.07)$ & $39.01(11.81-73.89)$ & 0.3466 \\
\hline Patient sex & $\begin{array}{l}\text { Female } \\
\text { Male }\end{array}$ & $\begin{array}{l}33.59 \%(44) \\
66.41 \%(87)\end{array}$ & $\begin{array}{l}42.98 \%(196) \\
57.02 \%(260)\end{array}$ & 0.0677 \\
\hline Donor sex & $\begin{array}{l}\text { Female } \\
\text { Male }\end{array}$ & $\begin{array}{l}46.56 \%(61) \\
53.44 \%(70)\end{array}$ & $\begin{array}{l}45.61 \%(208) \\
54.39 \%(248)\end{array}$ & 0.9258 \\
\hline Donor/Patient sex & $\begin{array}{l}\text { Female to female } \\
\text { Female to male } \\
\text { Male to female } \\
\text { Male to male }\end{array}$ & $\begin{array}{l}16.79 \%(22) \\
29.77 \%(39) \\
16.79 \%(22) \\
36.64 \%(48)\end{array}$ & $\begin{array}{l}20.61 \%(94) \\
25 \%(114) \\
22.37 \%(102) \\
32.02 \%(146)\end{array}$ & 0.2844 \\
\hline Relation to donor & $\begin{array}{l}\text { Sibling } \\
\text { Child } \\
\text { Parent } \\
\text { Other }\end{array}$ & $\begin{array}{l}37.4 \%(49) \\
19.85 \%(26) \\
31.3 \%(41) \\
11.45 \%(15)\end{array}$ & $\begin{array}{l}26.75 \%(122) \\
41.67 \%(190) \\
15.13 \%(69) \\
16.45 \%(75)\end{array}$ & $<0.0001$ \\
\hline Host/Donor CMV status & $\begin{array}{l}\text { neg to neg } \\
\text { pos to neg } \\
\text { neg to pos } \\
\text { pos to pos }\end{array}$ & $\begin{array}{l}13.18 \%(17) \\
5.43 \%(7) \\
15.5 \%(20) \\
65.89 \%(85)\end{array}$ & $\begin{array}{l}12.81 \%(57) \\
4.04 \%(18) \\
21.12 \%(94) \\
62.02 \%(276)\end{array}$ & 0.5169 \\
\hline Sorror HCT-CI & $\begin{array}{l}\text { HCT-CI 0 } \\
\text { HCT-CI 1-2 } \\
\text { HCT-CI } \geq 3\end{array}$ & $\begin{array}{l}54.14 \%(72) \\
29.32 \%(39) \\
16.54 \%(22)\end{array}$ & $\begin{array}{l}38.44 \%(173) \\
34.67 \%(156) \\
26.89 \%(121)\end{array}$ & 0.0033 \\
\hline Stem cell source & $\begin{array}{l}\text { BM } \\
\text { PB }\end{array}$ & $\begin{array}{l}38.17 \%(50) \\
61.83 \%(881)\end{array}$ & $\begin{array}{l}44.52 \%(2033) \\
55.48 \%(253)\end{array}$ & 0.2327 \\
\hline Time from diagnosis to set & & $19.9(2.45-66.1)$ & $12.95(0.95-62.6)$ & 0.0027 \\
\hline Disease status at SCT & $\begin{array}{l}\text { CR1 } \\
\text { CR2 }+ \\
\text { not CR }\end{array}$ & $\begin{array}{l}43.08 \%(56) \\
25.38 \%(33) \\
31.54 \%(41)\end{array}$ & $\begin{array}{l}34.89 \%(157) \\
23.33 \%(105) \\
41.78 \%(188)\end{array}$ & 0.0954 \\
\hline Number of CT cycle to reach CR1 & $\begin{array}{l}1 \\
>1 \\
\text { Missing }\end{array}$ & $\begin{array}{c}27(48.2 \%) \\
14(25 \%) \\
15(26.8 \%)\end{array}$ & $\begin{array}{c}66(42 \%) \\
49(31.2 \%) \\
42(26.8 \%)\end{array}$ & 0.638 \\
\hline Secondary AML & $\begin{array}{l}\text { no } \\
\text { yes }\end{array}$ & $\begin{array}{l}\mathrm{NA} \\
\mathrm{NA}\end{array}$ & $\begin{array}{c}78.51 \%(358) \\
21.49 \%(98)\end{array}$ & \\
\hline Ph+ALL & $\begin{array}{l}\text { No } \\
\text { Yes } \\
\text { missing }\end{array}$ & $\begin{array}{l}47.3 \%(62) \\
28.2 \%(37) \\
24.4 \%(32)\end{array}$ & $\begin{array}{l}\mathrm{NA} \\
\mathrm{NA} \\
\mathrm{NA}\end{array}$ & \\
\hline Cytogenetic risk & $\begin{array}{l}\text { good } \\
\text { interm } \\
\text { poor } \\
\text { NA/failed }\end{array}$ & $\begin{array}{l}\text { NA } \\
\text { NA } \\
\text { NA } \\
\text { NA }\end{array}$ & $\begin{array}{l}7.24 \%(33) \\
50.22 \%(229) \\
21.93 \%(100) \\
20.61 \%(94)\end{array}$ & \\
\hline
\end{tabular}

SCT stem cell transplant, CT chemotherapy, HCT-CT hematopoietic cell transplantation comorbidity index, CR complete remission, AML acute myeloid leukemia, $\mathrm{Ph}+\mathrm{ALL}$ Philadelphia positive chromosome acute lympholastic leukemia, NA not applicable

patients, year of transplantation, source of stem cells, and diagnosis. In contrast, the patients reported more in detail were older, had been transplanted more frequently in advanced stage, and had been given more posttransplant cyclophosphamide (PT-Cy) for GVHD prophylaxis (Additional file 1: Table S1). Nevertheless, relapse incidence did not differ between the two groups (Fig. 1a), which is why we considered the cohort of patients reported more in detail as a representative.

Patients' and disease characteristics of the 587 patients with detailed information are described in Table 1 . Patients' median age was $37(18-76)$ years for ALL and 48 (18-78) years for AML $(p<0.0001)$. Conditioning regimens, graft vs host disease (GvHD) prophylaxis, and stem cell source are described in Table 2. Myeloablative conditioning regimens were mostly employed in ALL
(92 patients, $70.23 \%$ ) than in AML (221 patients, $48.46 \%)(p<0.001)$. No statistical differences were found in means of in vivo $\mathrm{T}$ cell depletion (PT-Cy vs antithymocyte globulin (ATG)) or source of stem cells (PB vs $\mathrm{BM}$ ) between the ALL and AML groups. ATG was used for in vivo $\mathrm{T}$ cell depletion in 46 patients with ALL (35.11\%) and 169 with AML (37.06\%) while posttransplant cyclophosphamide (PT-Cy) was applied in 85 ALL (64.89\%) and 87 AML (62.94\%) patients, respectively $(p=0.76)$. Peripheral blood stem cells were the stem cell source in 81 ALL (61.83\%) and 253 AML (55.48\%) patients, respectively $(p=0.233)$.

\section{Relapse incidence after haplo-SCT}

Relapse occurred in 197 out of 587 patients, 54 ALL (27\%) and 143 AML (73\%). Characteristics of relapsed 

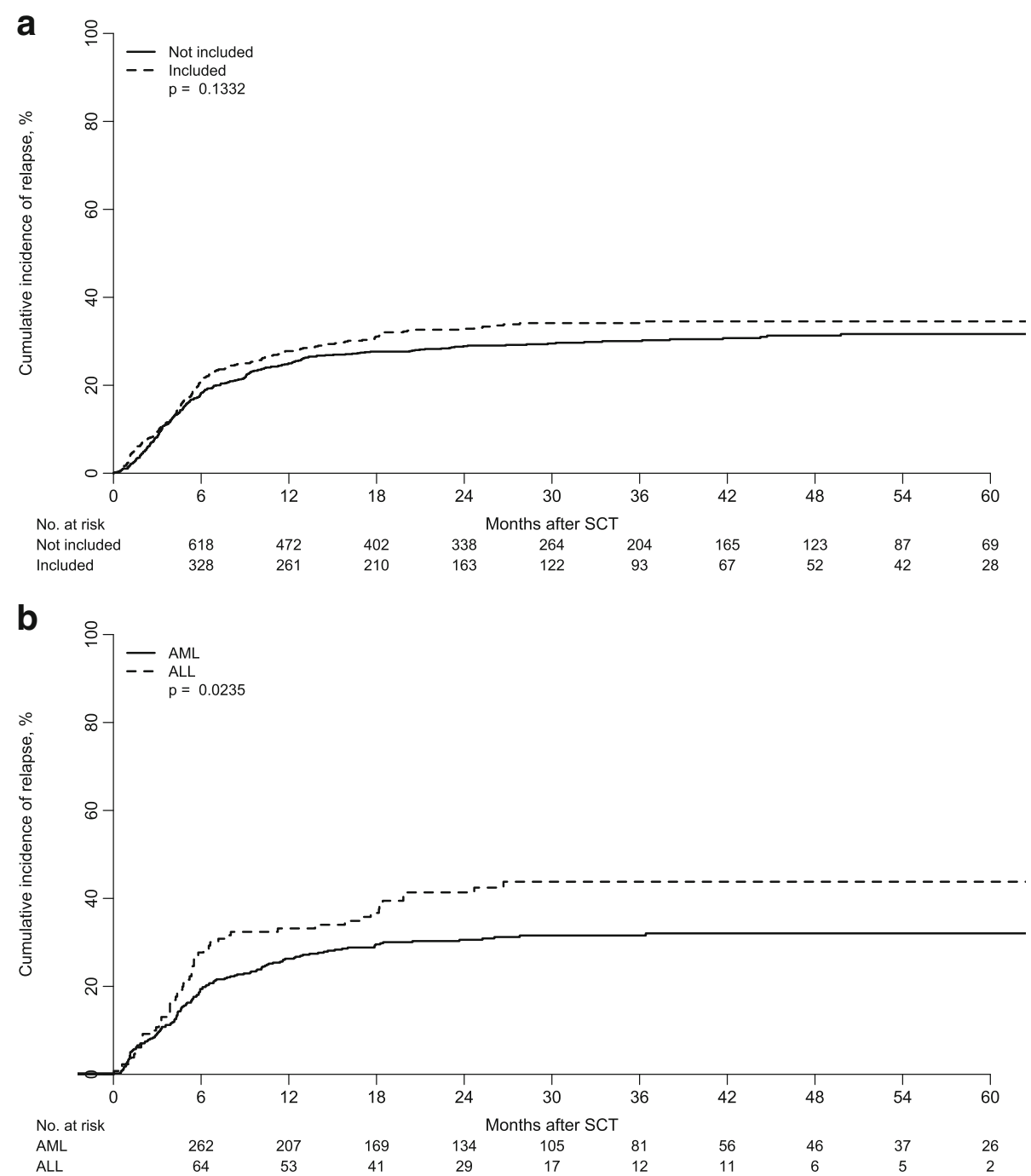

Fig. 1 a Incidence of relapse in the 587 patients included in our analysis and the 1065 patients transplanted in the same years in the EBMT centers but not included in the final analysis due to incomplete data. $\mathbf{b}$ Incidence of relapse in patients with ALL and AML included in our analysis

patients are described in Additional file 2: Table S2. The CI of relapse at 3 years was $44 \%(35-53 \%)$ for ALL and $32 \%(27-36 \%)$ for AML ( $p=0.023)$ (Fig. 1b).

Results for univariate analysis of risk factors for RI are shown in Additional file 3: Table S3. Among ALL patients, multivariate analysis revealed a lower RI after allo-SCT performed in CR1 (CR1 22\%, CR2 48\%, $p<$ 0.001; $C R \geq 2$ vs CR1: HR 2.98, $p=0.0087$; not $C R$ vs CR1: HR 14.83, $p<0.0001)$. Among ALL patients with advanced disease at transplantation, all but one experienced relapse. In addition, male donors were associated with higher RI (male vs female: HR 3.64, $p=$ 0.0002). Risk factors for a higher RI AML were disease status at transplant other than CR (not CR vs CR1: HR $3.95, p<0.0001)$, year of transplant (1-year increase: HR 0.91, $p=0.0425)$, and HCT-CI $\geq 3$ (HCT-C $\geq 3$ vs 0 : HR $1.75, p=0.0143$ ) (Table 3 ).
Characteristics and treatment of leukemia relapse post haplo-SCT

Median time from transplant to relapse was 4.91 months (0.03-62.77). Twenty-nine out of 197 (14\%) relapsed patients experienced extramedullary relapse (EMR), 14 (26\%) among ALL patients and 15 (10\%) among patients with AML. EMR showed a trend for a later onset after transplant than hematological relapse (6.1 vs 4.9 months) ( $p=0.08$ ).

Treatment of relapse varied and included withdrawal of immunosuppression, chemotherapy, tyrosine kinase inhibitors (TKI), donor lymphocyte infusion (DLI), and a second allo-SCT (Table 4). Strategies were used either alone or in combination.

Outcome and risk factors for survival after relapse

Median follow-up from date of relapse to last contact was 13 months. OS was $18 \%$ and $8 \%$ at 1 and 2 -year post relapse, respectively. Leukemia was by far the leading 
Table 2. Conditioning regimen for haplo-SCT

\begin{tabular}{|c|c|c|}
\hline \multirow[t]{13}{*}{ Conditioning regimen } & TBF & $27.43 \%(161)$ \\
\hline & TREO-FLU+/-TBI & $18.74 \%(110)$ \\
\hline & FLU-Cy+/-TBI & $12.62 \%(74)$ \\
\hline & BU-FLU-Cy & $10.90 \%(64)$ \\
\hline & BU-Cy & $4.26 \%(25)$ \\
\hline & $\mathrm{BU}+$ other & $4.26 \%(25)$ \\
\hline & Sequential* amsacrine-based & $3.75 \%(22)$ \\
\hline & BU-FLU & $3.42 \%(20)$ \\
\hline & FLU-MEL-Cy & $2.55 \%(15)$ \\
\hline & FLU-MEL-THIO & $2.38 \%(14)$ \\
\hline & FLU-THIO & $2.22 \%(13)$ \\
\hline & TREO + Other & $0.85 \%(5)$ \\
\hline & Other & $6.65 \%(39)$ \\
\hline \multirow[t]{2}{*}{ Myeloablative conditioning } & Yes & $53.32 \%(313)$ \\
\hline & No & $46.68 \%(274)$ \\
\hline \multirow[t]{9}{*}{ GvHD prophylaxis } & $\mathrm{PT}-\mathrm{Cy}+\mathrm{FK} 506+\mathrm{MMF}$ & $29.47 \%(173)$ \\
\hline & $\mathrm{PT}-\mathrm{Cy}+\mathrm{CSA}+\mathrm{MMF}$ & $22.49 \%(132)$ \\
\hline & $\mathrm{Rapa}+\mathrm{MMF}+\mathrm{ATG}$ & $16.01 \%(94)$ \\
\hline & $\mathrm{CSA}+\mathrm{MTX}+\mathrm{MMF}+\mathrm{ATG}$ & $9.88 \%(58)$ \\
\hline & $\mathrm{CSA}+\mathrm{MTX}+\mathrm{ATG}$ & $4.26 \%(25)$ \\
\hline & PT-Cy + Rapa + MMF & $4.26 \%(25)$ \\
\hline & $\mathrm{CSA}+\mathrm{ATG}$ & $3.91 \%(23)$ \\
\hline & Other PT-Cy & $7.16 \%(42)$ \\
\hline & Other ATG & $2.56 \%(15)$ \\
\hline \multirow[t]{2}{*}{ In vivo T-cell depletion } & ATG no PT-Cy & $36.63 \%(215)$ \\
\hline & PT-Cy no ATG & $63.37 \%(372)$ \\
\hline \multirow[t]{2}{*}{ Stem cell source } & $\mathrm{BM}$ & $43.1 \%(253)$ \\
\hline & $\mathrm{PB}$ & $56.9 \%(334)$ \\
\hline
\end{tabular}

TBF thiotepa-busulfan-fludarabine, TREO treosulfan, FLU fludarabine, TBI total body irradiation, Cy cyclophosphamide, BU busulfan, MEL melphalan, THIO thiotepa, PT-Cy post-transplant cyclophosphamide, FK506 tacrolimus, MMF micophenolate mofetil, Rapa rapamycin, ATG antithymocyte globulin, CSA cyclosporine "Sequential regimen of chemotherapy

cause of death (154 patients, 90\%), followed by infections (13 patients, 7.4\%). Two patients died from GvHD (1.1\%), while $3(1.5 \%)$ from other transplant-related causes.
The 1-year overall survival after relapse was higher for patients transplanted in remission (29\% CR1, 25\% CR $\geq$ $2,10 \%$ not in remission, $p=0.023$ ), for those with good/ intermediate cytogenetic ( $25 \%$ good/intermediate vs $9 \%$ 
Table 3. Multivariate analysis for relapse incidence after haplo-SCT for ALL and AML

\begin{tabular}{|c|c|c|c|c|c|c|c|}
\hline \multicolumn{8}{|l|}{ COX regression } \\
\hline \multicolumn{4}{|l|}{ ALL } & \multicolumn{4}{|l|}{ AML } \\
\hline \multirow{2}{*}{$\begin{array}{l}\text { RI } \\
\text { Disease status at SCT }\end{array}$} & & HR $(95 \% \mathrm{CI})$ & p-value & RI & & HR $(95 \% C I)$ & p-value \\
\hline & $\begin{array}{l}\text { CR2+ vs CR1 } \\
\text { not CR vs CR1 }\end{array}$ & $\begin{array}{c}2.98(1.32-6.72) \\
14.83(6.24-35.24)\end{array}$ & $\begin{array}{c}0.0087 \\
<0.0001\end{array}$ & $\begin{array}{l}\text { Age at SCT } \\
\text { Year of SCT }\end{array}$ & $\begin{array}{l}\text { one year increase } \\
\text { one year increase }\end{array}$ & $\begin{array}{l}0.99(0.97-1) \\
0.91(0.84-1)\end{array}$ & $\begin{array}{l}0.0666 \\
0.0425\end{array}$ \\
\hline \multirow[t]{2}{*}{ Donor/patient CMV } & $\begin{array}{l}\text { pos to neg vs neg to neg } \\
\text { neg to pos vs neg to neg }\end{array}$ & $\begin{array}{c}1.62(0.4-6.6) \\
0.81(0.26-2.55)\end{array}$ & $\begin{array}{c}0.501 \\
0.7188\end{array}$ & \multicolumn{2}{|c|}{ Disease status at SCT CR2+ vs CR1 } & $\begin{array}{l}1.28(0.73-2.25) \\
3.95(2.53-6.17)\end{array}$ & $\begin{array}{c}0.3877 \\
<0.0001\end{array}$ \\
\hline & pos to pos vs neg to neg & $2.33(0.94-5.74)$ & 0.067 & Donor sex & male vs female & $1.33(0.93-1.9)$ & 0.1142 \\
\hline \multirow[t]{2}{*}{ Donor sex } & male vs female & $3.64(1.84-7.22)$ & 0.0002 & Sorror HCT-CI & HCT-CI $1-2$ vs 0 & $1.11(0.72-1.71)$ & 0.6356 \\
\hline & & & & & HCT-C $\geq 3$ vs 0 & $1.75(1.12-2.75)$ & 0.0143 \\
\hline
\end{tabular}

$\overline{A L L}$ acute lymphoblastic leukemia, $A M L$ acute myeloid leukemia, $R /$ relapse incidence, $H R$ hazard ratio, SCT stem cell transplant, $C R$ complete remission, $H C T$ - $C l$ hematopoietic cell transplantation comorbidity index, CMV cytomegalovirus

in those with poor/NA, $p=0.004)$, for patients who relapsed more than 5 months after haplo-SCT $(26 \%>5$ months vs those who relapsed $\leq 5$ months $(10 \%, p>$ $0.0001)$ ), in patients having received bone marrow grafts (26\% BM, 11\% PB, $p=0.006$ ), and for patients without grade II-IV aGvHD (21\% no, $6 \%$ yes, $p=0.09)$. The prognostic factors for higher OS confirmed by multivariate analysis were remission at time of haplo-SCT, time from transplant to relapse ( $>5$ months), and stem cell source (BM) (Table 5 and Fig. 2a-c). In 49 out of 197 patients $(33 \%)$ that showed both remission at time of haplo-SCT and relapse $>5$ months from transplantation, the 1 - and 2 -year OS were $33 \%$ and $14 \%$, respectively $(p=0.003)$.

Since the reason why patients have been assigned to the different treatments could not be evaluated retrospectively, no comparison among different strategies could be performed. Second allo-SCT was performed in 29 relapsing patients; out of them, 9 were in CR $(\geq 2$, $31 \%)$, while 20 were in relapse $(69 \%)$ at the time of second haplo-SCT. The 1- and 2-year OS following the second allo-SCT were 25\% (13-48\%) and 12\% (4-35\%), respectively. Only 3 patients are alive at 6,29 , and 61 months from second allo-SCT.

\section{Discussion}

Leukemia relapse is the leading cause of failure after allo-SCT including in transplants from haploidentical donors [1-5, 24]. Most studies comparing haploidentical donors to matched unrelated or related donors did not find any overall differences in terms of leukemia relapse according to donor type $[6,11,12,25,26]$. In contrast, Ciurea et al. compared haplo-SCT to transplants from unrelated donors in AML and described a higher incidence of relapse after haplo-SCT after RIC regimens [10], whereas Luo et al. reported a lower incidence of relapse in patients with hematological malignancies undergoing haploidentical versus matched sibling donor SCT in a setting of ATG-based immunosuppression [27].

The current report represents a large registry-study focusing on relapse after haplo-SCT for acute leukemia analyzing risk factors, timing, treatment strategies, and

Table 4. Treatment of relapse after haplo-SCT

\begin{tabular}{|lccc|}
\hline Treatment & all & ALL & AML \\
None & & & \\
TKI & $61(31 \%)$ & $14(26 \%)$ & $47(32.9 \%)$ \\
DLI & $4(2 \%)$ & $3(5.5 \%)$ & $1(0.7 \%)$ \\
Second allo-SCT & $10(5.1 \%)$ & $2(3.6 \%)$ & $8(5.6 \%)$ \\
Chemotherapy alone & $12(6.1 \%)$ & $1(1.9 \%)$ & $11(7.7 \%)$ \\
Chemotherapy + TKI & $57(28.9 \%)$ & $15(27.8 \%)$ & $42(29.4 \%)$ \\
Chemotherapy + TKI + second allo-SCT & $5(2.5 \%)$ & $3(5.5 \%)$ & $2(1.4 \%)$ \\
Chemotherapy + DLI & $1(0.5 \%)$ & $1(1.9 \%)$ & $0(0 \%)$ \\
Chemotherapy + second allo-SCT & $31(15.8 \%)$ & $10(18.5 \%)$ & $21(14.6 \%)$ \\
DLI + second allo-SCT & $9(4.6 \%)$ & $4(7.4 \%)$ & $5(3.5 \%)$ \\
Chemotherapy + DLI + second allo-SCT & $1(0.5 \%)$ & $0(0 \%)$ & $1(0.7 \%)$ \\
& $6(3 \%)$ & $1(1.9 \%)$ & $5(3.5 \%)$ \\
Tot. & & & \\
\hline
\end{tabular}

ALL acute lymphoblastic leukemia, AML acute myeloid leukemia, SCT stem cell transplant, TKI tyrosine kinase inhibitors, DLI donor lymphocyte infusion 
Table 5. Multivariate analysis of risk factors for OS after relapse

\begin{tabular}{|lccc|}
\hline Cox for OS after relapse & HR & CI & p \\
CR vs not CR & & & \\
Relapse $\geq 5$ months vs $<5$ months & 0.7047 & $0.52-0.96$ & 0.028 \\
PB vs BM & 0.5304 & $0.39-0.73$ & $<0.0001$ \\
\hline
\end{tabular}

OS overall survival, $H R$ hazard ratio, $C$ confidence interval, $C R$ complete remission, $P B$ peripheral blood, $B M$ bone marrow

overall survival after relapse. In ALL, patients transplanted beyond CR1 had a higher RI after haplo-SCT. This finding is in line with extensive previous published literature [28-30] and confirm the importance of proceeding to transplant as soon as the patients is in CR1 for those patients with an indication for allo-SCT.

As part of registry-based study limitations, we were not able to study the impact of pre-transplant measurable residual disease on ALL relapse. Acute lymphoblastic leukemia immunophenotype was available only for a quarter of the patients so we could not analyze relapse incidence between B cell and T cell ALL. Nevertheless, in a previous publication from ALWP, Santoro et al. did not find any difference in haplo-SCT outcome between B-ALL and T-ALL [31].

Another risk factor for ALL relapse was donor gender; in particular, male donors were associated with a higher RI. As male donors were associated with a lower incidence of grade II-IV acute GvHD (aGvHD, Additional file 4: Table S4), one possible reason for the higher incidence of relapse could be a lower GVL effect. Recently, McCurdy et al. described a higher PFS after PT-Cy Haplo-SCT if grade II aGvHD had occurred [32]. Nakasone et al. [33] have previously reported lower incidence of relapse in a subset of male patients receiving allo-SCT from a female donor. Baron et al. [34] also reported a reduced incidence of acute leukemia relapse and a higher incidence of cGvHD in the combination of female donors to male patients. Of note, in our study, male donors were also a risk factor for a lower leukemia-free survival (LFS) and OS but not for higher NRM both in ALL and in AML.

Not unexpectedly, also in AML, disease status at transplant was a risk factor for higher relapse. In addition, patients with a HCT-CI $\geq 3$ and transplanted in older age had a higher incidence of relapse. These findings might be explained by a lower conditioning intensity in elderly patients and those transplanted earlier or with higher comorbidities. However, the importance of the intensity of the conditioning regimens in preventing leukemia relapse after allo-SCT is debated. Rubio et al. had recently reported on behalf of the ALWP of the EBMT a trend for a higher incidence of relapse in patients with AML receiving a haplo-SCT with RIC regimen [35]. Ciurea et al. showed a similar 1-year incidence of relapse in AML patients after haplo-SCT using RIC and MAC regimens [10]. In our current study, the intensity of conditioning regimen did not affect RI neither in ALL nor in AML. Of note, RIC regimens were associated to a lower incidence of aGvHD II-IV in ALL and lower NRM in AML without affecting OS and LFS (Additional file 4: Table S4). Importantly, according to our data (Table 3), incidence of AML relapse post haplo$\mathrm{SCT}$ is decreasing in transplants performed in more recent years. This might be in part due to modern approaches for the prevention of post-transplant relapse, including prophylactic or pre-emptive strategies such as hypomethylating agents, DLI, and anti-FLT3 inhibitors [36-39], although not enough data were available in the registry to study this aspect in detail.

Concerning stem cell source, Bashey et al. [40] have recently reported a lower incidence of relapse after haplo-SCT for acute leukemia using PBSC. In contrast, in our analysis, stem cell source did not affect RI neither in ALL nor in AML. Furthermore, bone marrow grafts were associated with a lower incidence of cGvHD in ALL patients without affecting OS, LFS, aGVHD, and NRM (Additional file 4: Table S4). Our current data are consistent with previous publication showing comparable results for $\mathrm{PBSC}$ or $\mathrm{BM}$ recipients in haplo-SCT [41].

Incidence of extramedullary relapse (EMR) was higher in our cohort comparing to previous reports ( $14 \%$ vs $4-$ $10 \%)$. A possible explanation could be the higher number of ALL patients in active disease at time of transplant, a well-known factor associated with EMR [42-45]. In agreement with previously published literature, EMR relapses occurred later than hematological relapses [45] (6.1 vs 4.91 months), even if it was only a trend in our data. The exact cause of late transplant-failure at extramedullary sites is unclear but may result from the development of immune tolerance at peripheral sites (which 

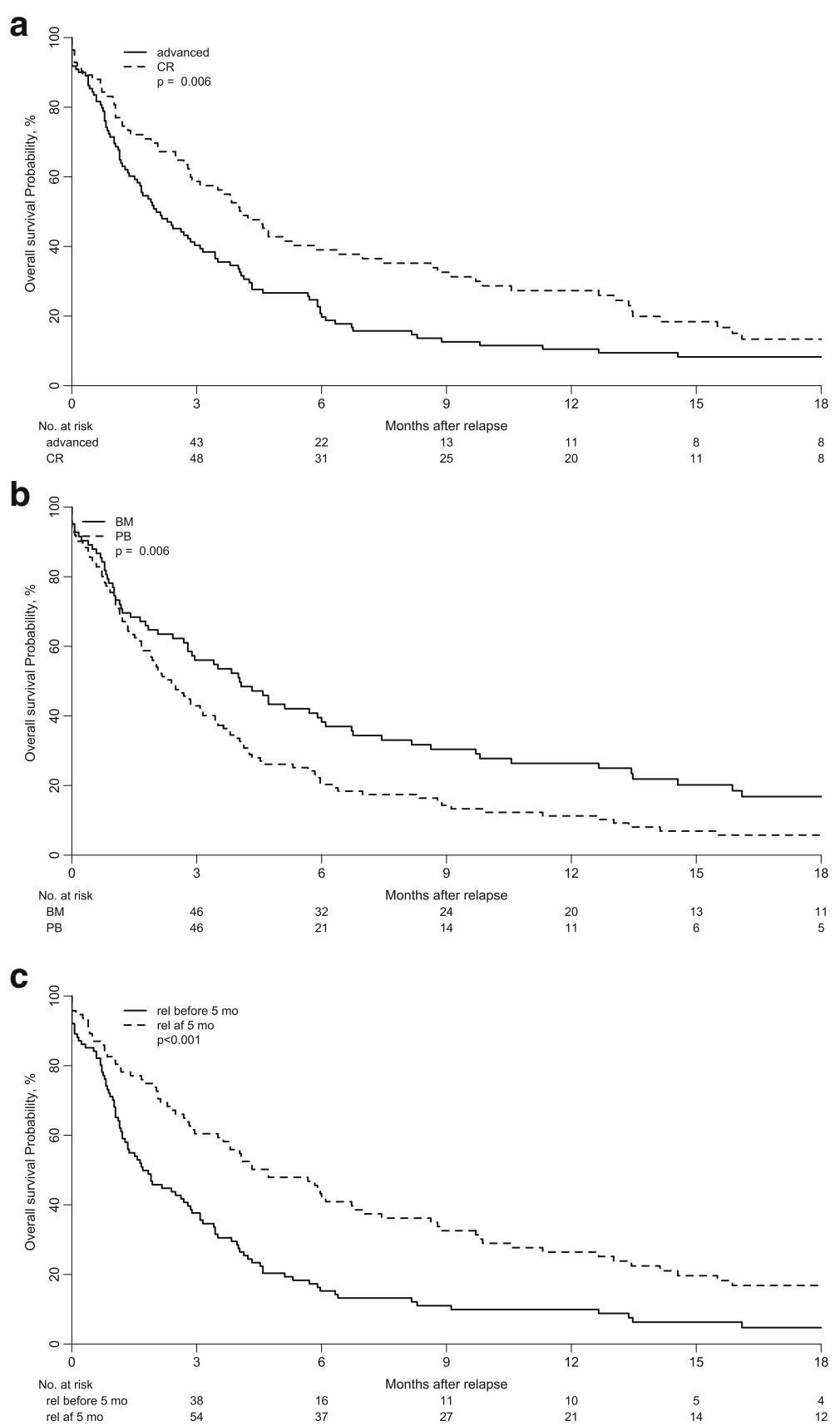

Fig. 2 Overall survival from relapse according to a disease status at time of haplo-SCT, $\mathbf{b}$ stem cell source, and $\mathbf{c}$ time from transplant to relapse

are also shielded to a degree from chemotherapy and conditioning regimens) $[46,47]$.

It is well established that patients with acute leukemia relapsing after a first allograft have a poor prognosis with a survival of only few months [48, 49]. Chemotherapy-based re-induction may result in remission rates of up to $70 \%$, but OS rarely exceeds $15-20 \%$ at 2 years $[48,49]$. DLI can be an additional option, but patients with relapsed leukemia rarely experience long-term benefit [50].
In the current study, various treatment modalities were used to conquer the leukemia relapses post haploSCT with a limited success rate in agreement with previous publications, regardless of donor type [36, 51-52]. Similar to the report by McCurdy et al. [26], we observed an inverse correlation between time to relapse post haplo-SCT and outcome, with better 1-year OS in patients relapsing $>5$ months post haplo-SCT. Further, haplo-SCT in CR was associated with improved outcome even after post-transplant relapse. Notably, we were able 
to identify a subgroup of patients with a better prognosis after relapse: Those 49 patients that were transplanted in remission and relapsed later than 5 months after transplant had better outcome and might be the most appropriate candidates for aggressive treatments such as second transplants. This approach is still intended to be curative; however, it is usually associated with higher toxicity and NRM [53-56].

Finally, stem cell source for the initial haplo-SCT influenced OS after relapse. Patients that received BM experienced a higher 1-year OS after relapse post haplo-SCT in comparison to those transplanted with PB $(11 \%$ vs $2 \%)$. One explanation could be the slightly higher incidence of cGvHD, which is usually associated with GvL effects, among patients receiving PB (Additional file 4: Table S4, also shown by Bashey and colleagues [40]). This might indicate a kind of resistance against GvL effects in those patients developing relapse.

In summary, within the limitations of a retrospective registry study, this analysis underscores the importance of remission of disease at time of haplo-SCT and coordinated timing of transplants, aiming in both lowering relapse incidence and increasing survival among those patients who develop relapse anyway. Donor gender, patient comorbidities, and year of transplantation are additional prognostic factors for leukemia relapse. Overall survival after relapse is dismal, but we were able to identify a subgroup of patients with better prognosis, those transplanted in complete remission and relapsing $>5$ months after haplo-SCT.

If confirmed in further studies, these findings may contribute to the early identification of patients at higher risk of relapse after haplo-SCT. Furthermore, they can help to overcome some of the risk factors for relapse in the pre-transplant setting or precociously planning posttransplant maintenance strategies. Finally, they can help us in selecting those patients that could better benefit from further treatments after relapse. Prospective trials comparing the different post-relapse therapeutic strategies may further help in dissecting the role of each treatment modality (Additional file 5: Table S5).

\section{Additional files}

Additional file 1: Table S1. Characteristic of the 587 patients included in our analysis and the 1065 patients transplanted in the same years in the EBMT centres but not included in the final analysis due to incomplete data. (DOCX $19 \mathrm{~kb}$ )

Additional file 2: Table S2. Characteristics of relapsed patients. (DOCX $25 \mathrm{~kb}$ )

Additional file 3: Table S3. Univariate analysis for RI in ALL and AML. (DOCX $21 \mathrm{~kb}$ )

Additional file 4: Table S4. COX regression for ALL and AML. (DOCX $22 \mathrm{~kb}$ )
Additional file 5: Table S5. EBMT participating centers. (DOCX 20 kb)

\section{Abbreviations}

AL: Acute leukemia; ALL: Acute lymphoblastic leukemia; ALWP: Acute Leukemia Working Party; AML: Acute myeloid leukemia; ATG: Antithymocyte globulin; BM: Bone marrow; CR: Complete remission; DLI: Donor leukocyte infusion; EBMT: European Society for Blood and Marrow Transplantation; EMR: Extramedullary relapse; GVHD: Graft vs host disease; GVL: Graft vs leukemia; HCT-Cl: Hematopoietic cell transplantation-specific comorbidity index; HLA: Human leukocyte antigen; LFS: Leukemia-free survival; MAC: Myeloablative conditioning regimens; MED-A: Minimum essential data A; NRM: Non-relapse mortality; OS: Overall survival; PB: Peripheral blood; PT-Cy: Post-transplant cyclophosphamide; Rl: Relapse incidence; RIC: Reduced-intensity conditioning; SCT: Stem cell transplantation; TBI: Total body irradiation; TKI: Tyrosine kinase inhibitors

\section{Acknowledgements}

The authors thank all transplant centers of the EBMT group for reporting to the registry the data included in this analysis. A list of the participating EBMT centers appears in Additional file 5: Table S5.

\section{Authors' contributions}

$\mathrm{SP}, \mathrm{CS}, \mathrm{AB}$, and $\mathrm{ML}$ designed research and wrote the paper. $\mathrm{MH}$ collected and checked the data and contacted transplantation centers. $\mathrm{AB}$ and $\mathrm{ML}$ analyzed the data. FC, JT, MM, and AN provided the data and wrote the paper. AR wrote the paper. WA, YK, ZG, BB, DW, DB, DB, and Gl provided the data. All authors read and approved the final manuscript.

Funding

The authors declare that they have no competing interests.

\section{Availability of data and materials}

The datasets used and/or analyzed during the current study are available from the corresponding author on reasonable request.

\section{Ethics approval and consent to participate}

Data for this retrospective multicenter analysis were provided and approved by the ALWP of the EBMT registry. Since 1990, patients have provided informed consent authorizing the use of their personal information for research purposes.

\section{Consent for publication}

Not applicable

\section{Competing interests}

The authors declare that they have no competing interests.

\section{Author details}

${ }^{1}$ Hematology and Bone Marrow Transplant Unit, San Raffaele Scientific Institute, Milan, Italy. ${ }^{2}$ Service d'Hématologie et Thérapie Cellulaire, Hôpital Saint Antoine, AP-HP, Paris, France. ${ }^{3}$ INSERM, UMRs 938, Paris, France.

${ }^{4}$ Universitätsklinik Augsburg, II Medizinische Klinik, Augsburg, Germany. ${ }^{5}$ Hematology Division-Stem Cell Transplant Unit, University of Rome Tor Vergata, Rome, Italy. ${ }^{6}$ Stem Cell Transplant Unit, Medical Park Hospitals, Antalya, Turkey. ${ }^{7}$ Bone Marrow Transplantation Department, Anadolu Medical Center Hospital, Kocaeli, Turkey. ${ }^{8}$ LMU-University Hospital of Munich-Grosshadern, Medizinischen Klinik III, Munich, Germany. ${ }^{9}$ A.O.U Citta della Salute e della Scienza di Torino, Presidio Molinette, Torino, Italy. ${ }^{10}$ First Affiliated Hospital of Soochow University, Suzhou 215006, Jiangsu, China.

${ }^{11}$ Programme de Transplantation \& Therapie Cellulaire, Institut Paoli Calmettes, Marseille, France. ${ }^{12}$ Dept. of Bone Marrow Transplantation, University Hospital, 45122 Essen, Germany. ${ }^{13}$ Centro Unico Regionale Trapianti, Alberto Neri, Bianchi-Melacrino-Morelli, Reggio Calabria, Italy. ${ }^{14}$ Department of Pediatric Hematology and Oncology, IRCCS Bambino Gesù Children's Hospital, 00165 Roma, Italy. ${ }^{15}$ Université Pierre et Marie Curie, Paris, France. ${ }^{16}$ Hematology and Bone Marrow Transplantation Division, Chaim Sheba Medical Center, Tel-Hashomer, Israel. ${ }^{17}$ Sackler School of Medicine, Tel Aviv University, Tel Aviv, Israel. ${ }^{18}$ ALWP office, Hopital Saint Antoine, Paris, France. ${ }^{19}$ University Vita-Salute San Raffaele, Milan, Israel. 
Received: 26 March 2019 Accepted: 14 June 2019 Published online: 04 July 2019

\section{References}

1. Luznik L, O'Donnell PV, Symons HJ, Chen AR, Leffell MS, Zahurak M, et al. HLA-haploidentical bone marrow transplantation for hematologic malignancies using nonmyeloablative conditioning and high-dose, posttransplantation cyclophosphamide. Biol Blood Marrow Transplant. 2008;14:641-50

2. Raiola AM, Dominietto A, Ghiso A, Di Grazia C, Lamparelli T, Gualandi F, et al. Unmanipulated haploidentical bone marrow transplantation and posttransplantation cyclophosphamide for hematologic malignancies after myeloablative conditioning. Biol Blood Marrow Transplant. 2013;19:117-22.

3. Di Bartolomeo P, Santarone S, De Angelis G, Picardi A, Cudillo L, Cerretti R, et al. Haploidentical, unmanipulated, G-CSF-primed bone marrow transplantation for patients with high-risk hematologic malignancies. Blood. 2013;121:849-57.

4. Peccatori J, Forcina A, Clerici D, Crocchiolo R, Vago L, Stanghellini MT, et al. Sirolimus-based graft-versus-host disease prophylaxis promotes the in vivo expansion of regulatory $T$ cells and permits peripheral blood stem cell transplantation from haploidentical donors. Leukemia. 2015;29:396-405.

5. Ji SQ, Chen HR, Wang HX, Yan HM, Zhu L, Liu J, et al. G-CSF-primed haploidentical marrow transplantation without ex vivo T cell depletion: an excellent alternative for high-risk leukemia. Bone Marrow Transplant. 2002; 30:861-6.

6. Piemontese S, Ciceri F, Labopin M, Arcese W, Kyrcz-Krzemien S, Santarone S, et al. A comparison between allogeneic stem cell transplantation from unmanipulated haploidentical and unrelated donors in acute leukemia. J Hematol Oncol. 2017;19:10-24

7. Ruggeri A, Sun Y, Labopin M, Bacigalupo A, Lorentino F, Arcese W, et al. Post-transplant cyclophosphamide versus anti-thymocyte globulin as graftversus-host disease prophylaxis in haploidentical transplant. Haematologica. 2017;102:401-10.

8. Bashey A, Zhang X, Sizemore CA, Manion K, Brown S, Holland HK, et al. Tcell-replete HLA-haploidentical hematopoietic transplantation for hematologic malignancies using posttransplantation cyclophosphamide results in outcomes equivalent of contemporaneous HLA-matched related or unrelated donor transplantation. J Clin Oncol. 2013:31:1310-6.

9. Slade M, DiPersio JF, Westervelt P, Vij R, Schroeder MA, Romee R. Haploidentical hematopoietic cell transplant with post-transplant cyclophosphamide and peripheral blood stem cell grafts in older adults with acute myeloid leukemia or myelodysplastic syndrome. Biol Blood Marrow Transplant. 2017;23:1736-43.

10. Ciurea SO, Zhang M-J, Bacigalupo A, Bashey A, Appelbaum FR, Aljitawi OS, et al. Haploidentical transplant with post-transplant cyclophosphamide versus matched unrelated donor transplant for acute myeloid leukemia. Blood. 2015;126:1033-40.

11. Ringdén O, Labopin M, Ciceri F, Velardi A, Bacigalupo A, Arcese W, et al. Is there a stronger graft-versus-leukemia effect using HLA-haploidentical donors compared with HLA-identical siblings? Leukemia. 2016;30:447-55.

12. Salvatore D, Labopin M, Ruggeri A, Battipaglia G, Ghavamzadeh A, Ciceri F, et al. Outcomes of hematopoietic stem cell transplantation from unmanipulated haploidentical versus matched sibling donor in patients with acute myeloid leukemia in first complete remission with intermediate or high-risk cytogenetics: a study from the Acute Leukemia Working Party of the European Society for Blood and Marrow Transplantation Haematologica. 2018 May 10. pii: haematol.2018.189258. doi: https://doi.org/ 10.3324/haematol.2018.189258. [Epub ahead of print]

13. Zhang YY, Mo XD, Zhang XH, Xu LP, Wang Y, et al. FLT3 internal tandem duplication does not impact prognosis after haploidentical allogeneic hematopoietic stem cell transplantation in AML patients. Bone Marrow Transplantation. Feb 2019. https://doi.org/10.1038/s41409-019-0456-X.

14. Shimoni A, Labopin M, Lorentino F, Van Lint MT, Koc Y, et al. Killer cell immunoglobulin-like receptor ligand mismatching and outcome after haploidentical transplantation with post-transplant cyclophosphamide. Leukemia. 2019;33(1):230-9.

15. Raiola AM, Risitano A, Sacchi N, Giannoni L, Signori A, et al. Impact of HLA disparity in haploidentical bone marrow transplantation followed by highdose cyclophosphamide. Biol Blood Marrow Transplant. 2018;24(1):119-26.

16. Huang XJ, Liu DH, Liu KY, Xu LP, Chen H, et al. Treatment of acute leukemia with unmanipulated HLA-mismatched/haploidentical blood and bone marrow transplantation. Biol Blood Marrow Transplant. 2009;15(2):257-65.
17. Sun W, Mo XD, Zhang XH, Xu LP, Wang Y, et al. Chemotherapy plus DLI for relapse after haploidentical HSCT: the biological characteristics of relapse influences clinical outcomes of acute leukemia patients. Bone Marrow Transplant. 2018 Dec 5. https://doi.org/10.1038/s41409-018-0406-z [Epub ahead of print]

18. Solh M, Zhang X, Connor K, Brown S, Solomon SR, et al. Post-relapse survival after haploidentical transplantation vs matched-related or matched-unrelated hematopoietic cell transplantation. Bone Marrow Transplant. 2016;51(7):949-54.

19. Yan CH, Wang JZ, Liu DH, Xu LP, Chen H, et al. Chemotherapy followed by modified donor lymphocyte infusion as a treatment for relapsed acute leukemia after haploidentical hematopoietic stem cell transplantation without in vitro T-cell depletion: superior outcomes compared with chemotherapy alone and an analysis of prognostic factors. Eur J Haematol. 2013;91(4):304-14.

20. Przepiorka D, Weisdorf D, Martin P, Klingemann HG, Beatty P, Hows J, et al. 1994 consensus conference on aGvHD grading. Bone Marrow Transplant. 1995;15:825-8.

21. Lee SJ, Vogelsang G, Flowers ME. Chronic graft versus host disease. Biol Blood Marrow Transplant. 2003;9:215-33.

22. MED - AB Forms Manual. A guide to the completion of the EBMT HSCT Med-AB forms. Last modified: 14/05/2018. http://www.ebmt.org/sites/ default/files/2018-03/MED-AB\%20Forms\%20Manual.pdf.

23. Sorror ML, Maris MB, Storb R, Baron F, Sandmaier BM, Maloney DG, et al. Hematopoietic cell transplantation (HCT)-specific comorbidity index: a new tool for risk assessment before allogeneic HCT. Blood. 2005;106:2912-9.

24. Goldstone AH, Richards SM, Lazarus HM, Tallman MS, Buck G, Fielding AK, et al. In adults with standard-risk acute lymphoblastic leukemia, the greatest benefit is achieved from a matched sibling allogeneic transplantation in first complete remission, and an autologous transplantation is less effective than conventional consolidation/maintenance chemotherapy in all patients: final results of the International ALLTrial (MRC UKALLXII/ECOG E2993). Blood. 2008;111:1827-1833.

25. Di Stasi A, Milton DR, Poon LM, Hamdi A, Rondon G, Chen J, et al. Similar transplantation outcomes for acute myeloid leukemia and myelodysplastic syndrome patients with haploidentical versus 10/10 human leukocyte antigen-matched unrelated and related donors. Biol Blood Marrow Transplant. 2014;20:1975-81.

26. McCurdy SR, Kasamon YL, Kanakry CG, Bolaños-Meade J, Tsai HL, Showel $\mathrm{MM}$, et al. Comparable composite endpoints after HLA-matched and HLAhaploidentical transplantation with post-transplantation cyclophosphamide. Haematologica. 2017 Feb;102:391-400.

27. Luo Y, Xiao H, Lai X, Shi J, Tan Y, He J, et al. T-cell-replete haploidentical HSCT with low-dose anti-T-lymphocyte globulin compared with matched sibling HSCT and unrelated HSCT. Blood. 2015;124:2735-43.

28. Goldstone AH, Richards SM, Lazarus HM, Tallman MS, Buck G, Fielding AK, et al. In adults with standard-risk acute lymphoblastic leukemia, the greatest benefit is achieved from a matched sibling allogeneic transplantation in first complete remission, and an autologous transplantation is less effective than conventional consolidation/maintenance chemotherapy in all patients: final results of the InternationalALLTrial (MRC UKALLXII/ECOG E2993). Blood. 2008;111:1827-33.

29. Pidala J, Djulbegovic B, Anasetti C, Kharfan-Dabaja M, Kumar A. Allogeneic hematopoietic cell transplantation for adult acute lymphoblastic leukemia (ALL) in first complete remission (Review) Cochrane Database Syst Rev. 2011;(10):CD008818. https://doi.org/10. 1002/14651858.CD008818.pub2.

30. Bassan R, Hoelzer D. Modern therapy of acute lymphoblastic leukemia. J Clin Oncol. 2011;29:532-43.

31. Santoro N, Ruggeri A, Labopin M, Bacigalupo A, Ciceri F, et al. Unmanipulated haploidentical stem cell transplantation in adults with acute lymphoblastic leukemia: a study on behalf of the Acute Leukemia Working Party of the EBMT. J Hematol Oncol. 2017; 10: 113. Published online 2017 May 30. doi: https://doi. org/10.1186/s13045-017-0480-5

32. McCurdy SR, Kanakry CG, Tsai HL, Kasamon YL, Showel MM, Bolaños-Meade J, et al. Grade II acute graft-versus-host disease and higher nucleated cell graft dose improve progression-free survival after HLA-haploidentical transplant with post-transplant cyclophosphamide. Biol Blood Marrow Transplant. 2018;24:343-52.

33. Nannya Y, Kataoka K, Hangaishi A, Imai Y, Takahashi T, Kurokawa M. The negative impact of female donor/male recipient combination in allogeneic 
hematopoietic stem cell transplantation depends on disease risk. Transplant Int. 2011;24:469-76.

34. Baron F, Labopin M, Ruggeri A, Cornelissen JJ, Meijer E, Sengeloev H, et al. Impact of donor type in patients with AML given allogeneic 2 hematopoietic cell transplantation after low-dose TBI based regimen. Clin Cancer Res. 2018. Published OnlineFirst on March 19, 2018; DOI: https:/doi.org/10.1158/10780432.CCR-17-3622

35. Rubio MT, Savani B, Labopin M, Piemontese S, Polge E, Ciceri F, et al. Impact of conditioning intensity in T-replete haplo-identical stem cell transplantation for acute leukemia: a report from the acute leukemia working party of the EBMT. J Hematol Oncol. 2016;9:25.

36. Schroeder T, Rautenberg C, Haas R, Germing U, Kobbe G. Hypomethylating agents for treatment and prevention of relapse after allogeneic blood stem cell transplantation. Int J Hematol. 2018;107:138-50.

37. Schiller GJ, Tuttle P, Desai P. Allogeneic Hematopoietic Stem Cell Transplantation in FLT3-TTD-positive acute myelogenous leukemia: The Role for FLT3 Tyrosine Kinase Inhibitors Post-Transplantation. Biol Blood Marrow Transplant. 2016;22:982-90

38. Orti G, Barba P, Fox L, Salamero O, Bosch F, et Valcarcel D. Donor lymphocyte infusions in AML and MDS: enhancing the graft-versusleukemia effect. Exp Hematol. 2017:48:1-11. doi: https://doi.org/10.1016/j. exphem.2016.12.004. Epub 2016 Dec 24.

39. Guillaume T, Malard F, Magro L, Labopin M, Tabrizi R, et al. Prospective phase II study of prophylactic low-dose azacitidine and donor lymphocyte infusions following allogeneic hematopoietic stem cell transplantation for high-risk acute myeloid leukemia and myelodysplastic syndrome. Bone Marrow Transplant. 2019 May 14. https://doi.org/10.1038/s41409-019-0536-y [Epub ahead of print].

40. Bashey A, Zhang M-J, SR MC. Mobilized peripheral blood stem cells versus unstimulated bone marrow as a graft source for T-cell-replete haploidentical donor transplantation Using Post-Transplant Cyclophosphamide. J Clin Oncol. 2017;35:3002-9.

41. Ruggeri A, Labopin M, Bacigalupo A, Gülbas Z, Koc Y, Blaise D, et al. Bone marrow versus mobilized peripheral blood stem cells in haploidentical transplants using post transplantation cyclophosphamide. Cancer. 2018;124:1428-37.

42. Mo XD, Kong J, Zhao T, Xu LP, Zhang XH, Liu DH, et al. Extramedullary relapse of acute leukemia after haploidentical hematopoietic stem cell transplantation: incidence, risk factors, treatment, and clinical outcomes. Biol Blood Marrow Transplant. 2014;20:2023-8.

43. Yoshihara S, Ikegame K, Kaida K, Taniguchi K, Kato R, Inoue T, et al. Incidence of extramedullary relapse after haploidentical SCT for advanced AML/ myelodysplastic syndrome. Bone Marrow Transplant. 2012;47:669-76.

44. Crucitti L, Crocchiolo R, Toffalori C, Mazzi B, Greco R, Signori A, et al. Incidence, risk factors and clinical outcome of leukemia relapses with loss of the mismatched HLA after partially incompatible hematopoietic stem cell transplantation. Leukemia. 2015;29:1143-52.

45. Shem-Tov N, Saraceni F, Danylesko I, Shouval R, Yerushalmi R, Nagler A, et al. Isolated extramedullary relapse of acute leukemia after allogeneic stem cell transplantation: different kinetics and better prognosis than systemic relapse. Biol Blood Marrow Transplant. 2017;23:1087-94.

46. Clark WB, Strickland SA, Barrett AJ, Savani BN. Extramedullary relapses after allogeneic stem cell transplantation for acute myeloid leukemia and myelodys-plastic syndrome. Haematologica. 2010;95:860-3.

47. Cunningham I. Extramedullary sites of leukemia relapse after transplant. Leuk Lymphoma. 2006;47:1754-67.

48. Schmid C, Labopin M, Nagler A, Bornhauser M, Finke J, Fassas A, et al. Donor lymphocyte infusion in the treatment of first hematological relapse after allogeneic stem cell transplantation in adults with acute myeloid leukaemia: a retrospective risk factors analysis and comparison with other strategies by the EBMT Acute Leukemia Working Party. Journal of Clinical Oncology. J Clin Oncol. 2007;25:4938-45.

49. Spyridonidis A, Labopin M, Schmid C, Volin L, Yakoub-Agha I, Stadler M, et al. Outcomes and prognostic factors of adults with acute lymphoblastic leukemia who relapse after allogeneic hematopoietic cell transplantation. An analysis on behalf of the Acute Leukemia Working Party of EBMT. Leukemia. 2012;26:1211-7.

50. Kolb HJ, Schattenberg A, Goldman JM, Hertenstein B, Jacobsen N, Arcese W, et al. Graft-versus-leukemia effect of donor lymphocyte transfusions in marrow grafted patients. Blood. 1995;86:2041-50.

51. De Freitas T, Marktel S, Piemontese S, Carrabba MG, Tresoldi C, Messina C, et al. High rate of hematological responses to sorafenib in FLT3-ITD acute myeloid leukemia relapsed after allogeneic hematopoietic stem cell transplantation. Eur J Haematol. 2015:96:629-36.

52. Rautenberg C, Nachtkamp K, Dienst A, Schmidt PV, Heyn C, Kondakci M, et al. Sorafenib and azacitidine as salvage therapy for relapse of FLT3-ITD mutated AML after allo-SCT. Eur J Haematol. 2016;98:348-54.

53. Christopeit M, Kuss O, Finke J, Bacher U, Beelen DW, Bornhauser M, et al. Second allograft for hematologic relapse of acute leukemia after first allogeneic stem-cell transplantation from related and unrelated donors: the role of donor change. J Clin Oncol. 2013;31:3259-71.

54. Mrsic M, Horowitz MM, Atkinson K, Biggs JC, Champlin RE, Ehninger G, et al. Second HLA-identical sibling transplants for leukemia recurrence. Bone Marrow Transplant. 1992;9:269-75.

55. Andreola G, Labopin M, Beelen D, Chevallier P, Tabrizi R, Bosi A, et al. Longterm outcome and prognostic factors of second allogeneic hematopoietic stem cell transplant for acute leukemia in patients with a median follow-up of $\geqslant 10$ years. Bone Marrow Transplant. 2015;50:1508-12.

56. Kharfan-Dabaja MA, Labopin M, Nishihori T, Bazarbachi A, Finke J, et al. Outcomes of post-allograft relapsed acute myeloid leukemia after donor lymphocyte infusion or a second allogeneic hematopoietic cell transplant: a study of the Acute Leukemia Working Party (ALWP) of the European Society for Blood and Marrow Transplantation (EBMT). Blood. 2017;130:273.

\section{Publisher's Note}

Springer Nature remains neutral with regard to jurisdictional claims in published maps and institutional affiliations.
Ready to submit your research? Choose BMC and benefit from:

- fast, convenient online submission

- thorough peer review by experienced researchers in your field

- rapid publication on acceptance

- support for research data, including large and complex data types

- gold Open Access which fosters wider collaboration and increased citations

- maximum visibility for your research: over $100 \mathrm{M}$ website views per year

At BMC, research is always in progress.

Learn more biomedcentral.com/submissions 